\title{
Geomorphological determinants of nekton use of intertidal salt marsh creeks
}

\author{
Dennis M. Allen ${ }^{1, *}$, Susanne S. Haertel-Borer ${ }^{2}$, Brian J. Milan ${ }^{3}$, David Bushek ${ }^{4}$, \\ Richard F. Dame ${ }^{5}$ \\ ${ }^{1}$ Baruch Marine Field Laboratory, University of South Carolina, PO Box 1630, Georgetown, South Carolina 29442, USA \\ ${ }^{2}$ Swiss Fisheries Advisory Service (FIBER) c/o EAWAG, Seestr. 79, 6047 Kastanienbaum, Switzerland \\ ${ }^{3}$ Coastal Fisheries Institute, Louisiana State University, Baton Rouge, Louisiana 70803, USA \\ ${ }^{4}$ Haskin Shellfish Research Lab, Rutgers University, 6959 Miller Avenue, Port Norris 08349, New Jersey, USA \\ ${ }^{5}$ Dept. of Marine Science, Coastal Carolina University, PO Box 261954, Conway, South Carolina 29528, USA
}

\begin{abstract}
Spatial variations in nekton use are often attributed to differences in the configuration and composition of habitat. We predicted that differences in nekton use among intertidal creeks were related to certain geomorphological characteristics. We measured or derived 28 features at 8 intertidal creeks in the high salinity North Inlet Estuary, South Carolina, USA. Nekton were collected simultaneously from all creeks once each season for 2 yr. Spatial variations in total abundance and biomass were greater than seasonal variations. Differences of 3- to 30-fold in resident and transient taxa densities occurred among creeks on the same date. Relative use (ranks) was similar among seasons and years. In canonical correlation analyses, depth, steepness, flow, and location were primary factors for total nekton and many taxa. Creeks that were shallow, broad, and filled and emptied slowly supported the greatest use. Total nekton use was not related to creek size, amount of edge, or oyster bottom. Grass shrimp Palaemonetes spp., numerically dominant in $83 \%$ of the collections, responded most to creek shape. Mummichog Fundulus heteroclitus favored shallow creeks with low flow and low proportions of submerged bottom at low tide. Juvenile spot Leiostomus xanthurus and pinfish Lagodon rhomboides were associated with the same features throughout their seasonal periods of occurrence. Persistent differences in nekton use of adjacent intertidal creeks might be explained by behavioral selection for preferred conditions and reoccupation of selected creeks. Geomorphological variations are significant among sites and must be considered when assessing factors affecting nekton use along salinity and other environmental gradients.
\end{abstract}

KEY WORDS: Nekton - Intertidal creeks $\cdot$ Salt marsh $\cdot$ Estuaries $\cdot$ Habitat structure $\cdot$ Fish behavior . Oysters $\cdot$ Bio-physical coupling

\section{INTRODUCTION}

Understanding relationships between organisms and habitats is an especially difficult challenge for investigators interested in motile animals in tidal systems. With a wide range of patterns and processes operating simultaneously on many spatial and temporal scales and an inability to measure all relevant abiotic and biotic factors, estuarine ecologists are usually forced to select a subset of conditions for hypothesis testing. Recently, the hierarchical landscape approach provides insights into the importance of landscape structure at different scales to the distribution of nekton (Pittman et al. 2004), but programs that require simultaneous measurements at multiple spatial scales are difficult to sustain through seasons and years. More often, investigators focus their research efforts on nekton-habitat relationships at fairly fine spatial scales and make repeated measurements over longer periods of time so that changes in taxonomic and life stage composition can be addressed. Many studies in estuarine systems have compared patterns of nekton use between habitat types such as the vegetated marsh surface, non- 
vegetated edges and intertidal creeks (see review by Minello et al. 2003).

Intertidal creeks are prominent features of the salt marsh landscape where they connect permanently flooded waterways and the vegetated marsh surface. Creeks that begin flooding shortly after low tide and remain inundated through most of the tidal cycle function as primary conduits for hydrologic and material exchanges between subtidal channels and the intertidal landscape, which often include mudflats, oyster reefs and marsh. Densities, sizes, shapes and bottoms of intertidal creeks vary considerably within and among estuaries. Short-term fluctuations in physical conditions of the water column within flooded creeks generally exceed those in major channels and open waterways. Intertidal creeks closest to the uplands are most variable due to the influences of freshwater runoff and development within adjacent watersheds (Holland et al. 2004).

Fishes and motile invertebrates use flooded intertidal creeks to forage and find refuge from aquatic predators (McIvor \& Rozas 1996, Kneib 1997, Gibson 2003). Some nekton use intertidal creeks as corridors to access the marsh (Rozas et al. 1988), but these channels can also serve as terminal destinations for other taxa and life stages that do not move into the marsh at high tide (Cain \& Dean 1976). Most tidal migrants return to subtidal areas during low tide, but some remain in permanently submerged portions (pools) of intertidal creeks which may serve as staging areas for animals that move into higher intertidal areas when these are flooded (Webb \& Kneib 2002). Whether nekton feed on the marsh (Cicchetti \& Diaz 2000, Kneib 2000) or within the creek (Cattrijsse et al. 1994), intertidal creeks play a key role in facilitating the 'trophic transfer' of biomass and energy between the salt marsh, open waters and the coastal ocean (Kneib 1997, Deegan et al. 2000).

Spatial variations in nekton use of creeks have been attributed to salinity (Weinstein et al. 1980, Able et al. 2001), dimensions and stream order (Rozas \& Odum 1987, Desmond et al. 2000), and surrounding landscape structure (Webb \& Kneib 2002). Despite widespread recognition of the high utilization of intertidal creeks by nekton, relationships between the internal composition and configuration of creeks and nekton use have not been explored. In this study, we quantified relationships between hydrogeomorphological characteristics of intertidal salt marsh creeks and the use of this habitat by fishes, shrimps and crabs. We predicted that: (1) the magnitude of nekton use varies considerably among intertidal creeks, (2) variations in use are related to differences in certain physical characteristics of creeks, and (3) patterns of use and associations with physical features vary among taxa and change seasonally.

\section{MATERIALS AND METHODS}

Study site. The study was conducted in North-Inlet Estuary (33 $\left.20^{\prime} \mathrm{N}, 79^{\circ} 10^{\prime} \mathrm{W}\right)$ in Georgetown County, South Carolina, USA. This warm temperate, high salinity, barrier island bounded system is dominated by Spartina alterniflora marsh (1650 ha). Creeks, intertidal flats and oyster reefs cover about 850 ha. The system is subject to semidiurnal tides with a mean tidal range of $1.5 \mathrm{~m}$. Due to shallow water depth and tidal currents, the creeks are generally well mixed and vertically homogeneous with respect to dissolved substances (Dame et al. 2000).

For this study, we selected 8 relatively large intertidal creeks that ranged from 153 to $517 \mathrm{~m}$ in length. The furthest distance between creeks was $1.3 \mathrm{~km}$ (Fig. 1). Four of the intertidal creeks (1 to 4) were associated with Clambank Creek, a major subtidal channel, and the other 4 intertidal creeks (5 to 8) were associated with Town Creek, a larger subtidal channel (Fig. 1). All 8 intertidal creeks were located above the mean low water level, and $>90 \%$ of the flooded volume flowed into the adjacent subtidal channel during

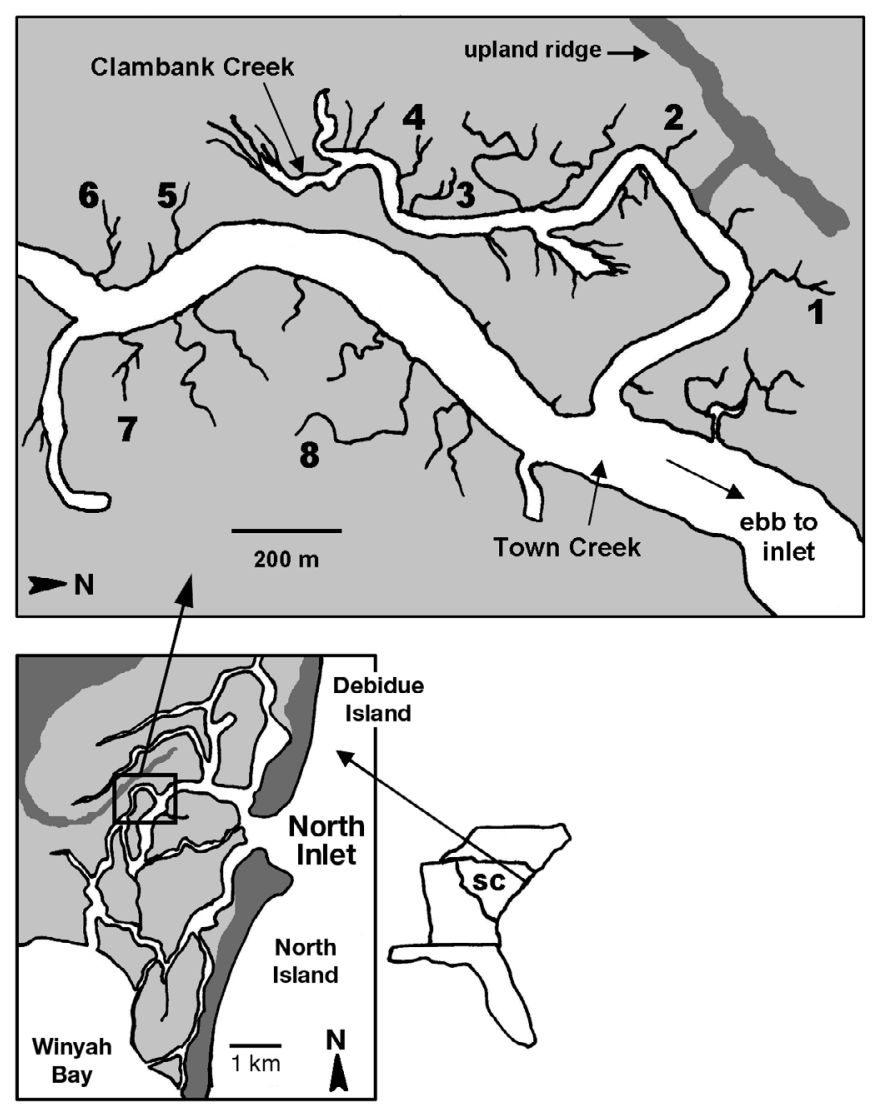

Fig. 1. Location of 8 intertidal creeks in North Inlet Estuary, South Carolina, USA. Uplands (dark grey) border intertidal marshes (light grey), and intertidal creeks (black) are connected to sub-tidal channels (white) 
every ebbing tide. Current velocities in the intertidal creeks were $<35 \mathrm{~cm} \mathrm{~s}^{-1}$ during peak flow.

Experimental design. Our study of relationships between nekton and the hydrogeomorphological features of the intertidal creeks was part of an investigation of the role of oysters in determining the structure and function of these intertidal systems. In that study, we used a replicated Before After Control Impact (BACI) design (Steward-Oaten et al. 1986) in which physical, chemical and biological (oysters and nekton) parameters were measured for 1 yr (March 1997 to February 1998) before the experimental manipulation. In the second year, living oysters were removed by hand from 4 of the 8 creeks and the same variables were measured for another year (March 1998 to February 1999). Dead shell base remained in areas from which live oysters were removed. Specific information about the design, methods and results of the oyster removal experiment on dissolved constituents can be found in Dame et al. $(2000,2002)$. The following methods include information most relevant to the nekton component.

Geomorphological variables. To characterize and quantify the physical configurations of the intertidal creeks, we measured 11 geomorphological features during topographic and bathymetric surveys (Dame et al. 2000). These were: length, width, cross-sectional area, elevation, number of pools, total bottom area, submerged bottom area, oyster bottom area, mud bottom area and intertidal bottom area outside the creek mouth. Total Station survey equipment (Topcon America, Model GTS2R) was used for standard dimensional variables and elevations. Tape measures and $1 \mathrm{~m}$ quadrants were used to classify and quantify the bottom types. We also determined values for 4 other variables (drainage area, location, branches and bends) from high-resolution aerial photographs. These and additional measurements were used to calculate values for 13 additional variables (e.g. volume, slope, roughness, meander, flow, percent submerged area and percent oyster area). There are 28 variables defined in Table 1. Although most live oysters were removed by hand from Creeks 1, 4, 5 and 7 in the second year of the experiment, the shell base and small live oysters remained in place and the percentage of oyster bottom (defined by the presence of shell) in each creek was similar between years.

Nekton sampling. Nekton abundance, biomass and species richness were determined for each creek in March (spring), June (early summer), August (late summer) and November (fall) during both years. Collections were made simultaneously from all 8 creeks using funnel-shaped block nets $(3 \mathrm{~mm})$ similar to those designed by Shenker \& Dean (1979). Each net was mounted on a rectangular PVC frame $(2.0 \mathrm{~m} \times 1.6 \mathrm{~m})$ which fitted into a permanently installed frame that oriented the net perpendicular to the creek bed and prevented nekton from escaping from the creek. The block net system covered the wet cross-sectional area near the mouth of the creek. Nets were set at slack high tide and only on early morning tides with predicted peak heights that were not sufficient to flood the marsh surface beyond the creek banks, thus eliminating the possibility of water and nekton exchanges between adjacent creeks at high tide. These tides and tide levels are referred to as bank full. At low tide, catches were removed from the nets and all pools were seined $(3 \mathrm{~mm})$. All samples were frozen and subsequently sorted to the lowest possible taxonomic level. Total numbers of individuals and total wet weight were determined for each taxon in all collections. Volume adjusted abundance (ind. $\left.\mathrm{m}^{-3}\right)$ and biomass $\left(\mathrm{g} \mathrm{m}^{-3}\right)$ values were used in all descriptions of patterns and all analyses to represent nekton use. Densities based on volume were considered better indicators of habitat use than area based adjustments for most taxa. Volume and bottom area were strongly correlated among creeks ( $\mathrm{p}<0.05, \mathrm{r}=0.91$ ), and our decision does not affect the patterns and relationships reported. Volume based densities can be converted to bottom area based densities using the following multipliers for Creeks 1 to 8 , respectively: $1.1,0.7,0.8,0.9,1.3,1.2,1.1,1.2$.

Water temperature, salinity and depth were measured when nets were set in the morning and again at sample retrieval that afternoon. Average water temperatures among creeks were similar in March $\left(10^{\circ} \mathrm{C}\right)$, June $\left(25^{\circ} \mathrm{C}\right)$ and August $\left(28^{\circ} \mathrm{C}\right)$ for both years; they were $16^{\circ} \mathrm{C}$ in November 1997 and $22^{\circ} \mathrm{C}$ in November 1998. Water temperature variations among creeks at the time of the high tide net set never exceeded $2^{\circ} \mathrm{C}$. Salinities were 31 to 35 psu on all 8 sampling dates; seasonal variations were $<5$ psu with slightly lower salinities occurring in March. Salinity differences among creeks never exceeded 2 psu on the same date. Bank full levels of flooding were similar in March, June and August (both years) and November 1997 with $<20 \mathrm{~cm}$ differences being observed among dates. Water levels in November 1998 were about $30 \mathrm{~cm}$ higher than the average and thus exceeded bank full status for about 30 min around high tide; this level was not high enough to allow mixing with adjacent marsh basins.

Statistical analysis. Characterization of creek geomorphology: Relationships among geomorphological and associated hydrographical features of the creeks were examined with Spearman correlation analysis. A correlation-based principal components analysis (PCA) with varimax rotation was performed on these variables to explore patterns of association among the variables. 
Table 1. Definitions of measured and derived physical variables of intertidal creeks used in the analyses of creek hydrogeomorphology and relationships between physical features and nekton. Bank full elevation refers to the top of the creek banks at the edge of the Spartina marsh. Units of measurement are given in Table 3

\begin{tabular}{|c|c|}
\hline Variable & Definition \\
\hline \multicolumn{2}{|l|}{ Size } \\
\hline Length & $\begin{array}{l}\text { Length of the main axis plus tributaries. Measurements along the centerlines of the main channel and } \\
\text { all tributaries (from the mouths to the ends where the channel bottom rises to the bank full elevation) } \\
\text { were summed to create this variable. Doubling of the length values provides a measure of creek edge. }\end{array}$ \\
\hline Width & $\begin{array}{l}\text { Mean width of the main channel of the creek. Distances between banks were measured every } 10 \mathrm{~m} \\
\text { from the mouth to the end of the main creek to determine mean width. The measurements were made } \\
\text { at the bank full elevation. }\end{array}$ \\
\hline Depth & $\begin{array}{l}\text { Mean depth of the main channel. Vertical distances between the flooded water surface (bank full } \\
\text { level) and creek bottom were measured at the same transects used to determine mean width. }\end{array}$ \\
\hline Cross-section & $\begin{array}{l}\text { Area of the cross-section of the creek mouth. This variable was calculated from multiple linear } \\
\text { measurements of the vertical plane that defined the mouth of the creek. Vertical measurements were } \\
\text { based on bank full elevation. }\end{array}$ \\
\hline Bottom area & $\begin{array}{l}\text { Total area of bottom of all types in the main creek and all tributaries. A survey using } 1 \mathrm{~m}^{2} \text { quadrants } \\
\text { and tape measure generated total bottom area. All roughly horizontal surfaces between creek banks } \\
\text { were included. }\end{array}$ \\
\hline \multicolumn{2}{|l|}{ Variables related to tide } \\
\hline Elevation & Surveyed elevation of the creek mouth relative to the mean low water level. \\
\hline Volume & $\begin{array}{l}\text { Volume of the creek (including tributaries) at bank full tide level. Calculations were based on survey } \\
\text { measurements of creek length, width and depth at bank full. }\end{array}$ \\
\hline \multicolumn{2}{|r|}{ 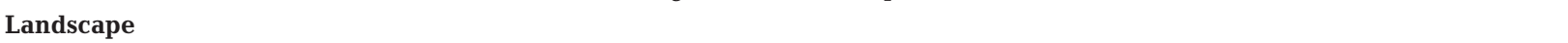 } \\
\hline Drainage area & $\begin{array}{l}\text { Area of intertidal marsh and mudflats between the edge of the creek and the estimated furthest dis- } \\
\text { tance flooding waters move outward before encountering flooding waters from adjacent drainage } \\
\text { basins. The boundaries were estimated from high resolution aerial photographs. }\end{array}$ \\
\hline Location & $\begin{array}{l}\text { Shortest linear distance from the creek mouth to the nearest upland forest edge. Distances were } \\
\text { determined from high resolution aerial photographs. }\end{array}$ \\
\hline \multicolumn{2}{|r|}{ 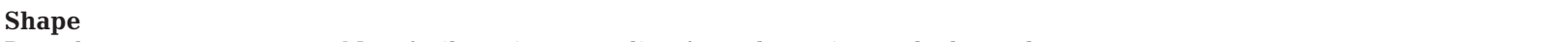 } \\
\hline Branches & No. of tributaries extending from the main creek channel. \\
\hline Bends & No. of locations at which the axis of the main channel changes direction by more than 10 degrees. \\
\hline Slope & $\begin{array}{l}\text { Slope of the regression line based on bottom elevation at } 10 \mathrm{~m} \text { intervals from the mouth to the end of } \\
\text { the main channel (where the bottom attains bank full elevation). }\end{array}$ \\
\hline \multicolumn{2}{|l|}{ Bottom features } \\
\hline Roughness & Irregularity of the bottom based on the coefficient of variation associated with mean depth. \\
\hline Pools & No. of depressions $\left(>5 \mathrm{~m}^{2}\right)$ in the intertidal creek bed that hold at least $10 \mathrm{~cm}$ of water at low tide. \\
\hline Submerged area & Area of creek bottom (pools) covered by at least $10 \mathrm{~cm}$ of water at low tide. \\
\hline Oyster area & $\begin{array}{l}\text { Area of creek bottom with living oysters and/or whole shell regardless of the composition of the } \\
\text { underlying sediment. Qualifying quadrants ranged from dense oyster reef to muddy areas with sparse } \\
\text { clusters or shell patches. }\end{array}$ \\
\hline Mud area & $\begin{array}{l}\text { Area of creek bottom with unconsolidated sediment but without oysters. Qualifying quadrants ranged } \\
\text { from uniform areas of soft mud to shelly mud without whole shell. Mud area plus oyster area equals } \\
\text { total bottom area. }\end{array}$ \\
\hline Outside oyster area & $\begin{array}{l}\text { Area of intertidal bottom with living oysters and/or whole shell immediately outside of the creek } \\
\text { mouth. The area calculation was based on the distance between the center of the intertidal creek } \\
\text { mouth and the low tide mark at the edge of the subtidal creek (width) and a standard } 20 \mathrm{~m} \text { length } \\
\text { ( } 10 \mathrm{~m} \text { either direction from the centerline). }\end{array}$ \\
\hline \multicolumn{2}{|l|}{ Proportions } \\
\hline$\%$ Submerged bottom & Ratio of submerged bottom area to (total) bottom area at low tide. \\
\hline$\%$ Oyster bottom & Ratio of oyster bottom area to total bottom area. \\
\hline$\%$ Outside oysters & Ratio of area of oysters outside of the creek mouth to total area outside of the creek mouth. \\
\hline \multicolumn{2}{|r|}{ 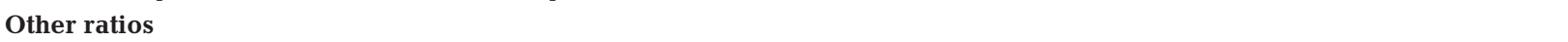 } \\
\hline Conduit & $\begin{array}{l}\text { Ratio of drainage area to (total) bottom area. Creeks with high ratios had large drainage areas relative } \\
\text { to the size of the creek (as indicated by bottom area). }\end{array}$ \\
\hline Axial dominance & Ratio of length of the main channel axis to the cumulative total length of all tributaries. \\
\hline Steepness & $\begin{array}{l}\text { Ratio of total volume of water at bank full level to total bottom area. Creeks with high ratios tended to } \\
\text { have square lateral profiles with steeper banks. }\end{array}$ \\
\hline Fringe & $\begin{array}{l}\text { Ratio of surface area at bank full to total bottom area. Creeks with high ratios tended to have more } \\
\text { shallow fringing areas. }\end{array}$ \\
\hline Flow & $\begin{array}{l}\text { Ratio of cross-sectional area at the mouth to total volume of water at bank full tide. Creeks with high } \\
\text { ratios tended to have large mouths relative to the volume of the creek; these creeks filled and emptied } \\
\text { more slowly than others. }\end{array}$ \\
\hline Meander & $\begin{array}{l}\text { Ratio of number of directional changes in the main channel axis (bends) to the length of the main } \\
\text { channel. }\end{array}$ \\
\hline Split & Ratio of number of branches to the length of the main channel. \\
\hline
\end{tabular}


Nekton data: A BACI analysis and the SAS-VARCOMP (SAS 1996) procedure were used to assess whether the removal of live oysters in 4 out of the 8 study creeks had an effect on nekton use of those creeks $(p<0.05)$. The statistical analysis of the BACI followed an adaptation of Stewart-Oaten et al. (1986) by Dame et al. (2002). The 8 creeks were considered replicates and assigned to 1 of 4 blocks $(1+2,3+4,5+6$ or $7+8$ ). A repeated-measures ANOVA using the treatment-control differences in each block as the response variables was performed using volume based abundance and biomass data; all data were log $(n+1)$ transformed prior to the analyses. The contributions of year, season and creek to the overall variation of final densities were assessed with the SAS-VARCOMP procedure. Both the BACI and the VARCOMP analyses were performed for both total nekton and individual taxa.

BACI revealed no significant differences in creek use by nekton before (1997) and after (1998) the removal of live oysters. This outcome was observed for both biomass and abundance for the total nekton and individual taxa. No differences were observed between years for species richness either. VARCOMP showed that spatial and/or seasonal patterns of nekton densities were stronger than interannual patterns for the total nekton and most individual taxa (Table 2). Accordingly, the 1997 and 1998 data were combined and treated as a single dataset in analyses that examined relationships between nekton and the geomorphological features of the creeks.

Nekton abundance and biomass densities and species richness were tested for differences among seasons by ANOVA using $\log (\mathrm{n}+1)$ transformed data. Partial Spearman correlation analyses were performed on abundance and biomass data by season to determine relationships among the different taxa. The analysis considers the correlation between a pair of variables in a variable set while holding constant the value of each of the other variables. Thereby, it takes the interactions of any of the other variables on the 2 variables in question into account (Zar 1996).

Linking nekton and creek data: Relationships between nekton and creek geomorphology were examined by canonical correlation analysis (SAS-CANCORR). Canonical correlation analyses were conducted sepa- rately for each season since habitat preferences may change depending on ontogenetic development and seasonal abundance. Densities of total nekton (biomass and abundance) and numbers of taxa (richness) were used in 1 set of analyses. Individual taxa (biomass and abundance) were tested separately. Both the predictor and criterion variables were rank transformed prior to the analyses. To account for the potential of autocorrelation in the input data set, correlation coefficients (r) of individual habitat variables (predictor variables) with the first canonical variable of the nekton variables (criterion variables) were used for the interpretation (Fischer \& Eckmann 1997). These values range from -1 to 1 and can be compared to each other by their absolute numerical value. In CANCORR, the number of variables of both variable sets together must be smaller than the number of sites (Jongman et al. 1995), so not all available creek parameters could be included in each analysis. Prior to canonical correlation analyses, Spearman correlations for the creek variables and nekton densities were calculated for both total nekton and individual taxa. Only those creek variables for which significant correlations were revealed were included in the analyses.
Table 2. Temporal and spatial variability for nekton densities in intertidal creeks in North Inlet Estuary. All values are variance component estimates (among years, among seasons, among creeks) calculated using the SAS variance component estimation procedure (PROC VARCOMP)

\begin{tabular}{|lcccccc|}
\hline \multirow{2}{*}{ Species } & \multicolumn{3}{c}{ Abundance } & \multicolumn{3}{c|}{ Biomass } \\
& Year Seasons & Creeks & Year & Seasons & Creeks \\
\hline $\begin{array}{l}\text { Total catch } \\
\text { Bay anchovy and }\end{array}$ & 317.9 & 600.5 & 923.9 & 1.7 & 440.1 & 749.3 \\
striped anchovy & 0.0 & 11.9 & 0.0 & $<0.1$ & 2.9 & 0.0 \\
$\begin{array}{l}\text { Anchoa spp. } \\
\text { Atlantic silverside }\end{array}$ & 0.1 & 1.3 & 2.1 & 0.0 & 5.9 & 3.4 \\
$\begin{array}{l}\text { Menidia menidia } \\
\text { Blue crab }\end{array}$ & $<0.1$ & $<0.1$ & $<0.1$ & $<0.1$ & 4.3 & 8.1 \\
$\begin{array}{l}\text { Callinectes sapidus } \\
\text { Brown shrimp }\end{array}$ & $<0.1$ & $<0.1$ & $<0.1$ & 0.0 & $<0.1$ & $<0.1$ \\
$\begin{array}{l}\text { Farfantepenaeus aztecus } \\
\text { Grass shrimp }\end{array}$ & 141.1 & 116.0 & 426.4 & 0.3 & 4.5 & 16.2 \\
$\begin{array}{l}\text { Palaemonetes spp. } \\
\text { Mummichog }\end{array}$ & $<0.1$ & 0.4 & 0.2 & 0.0 & 0.2 & 0.5 \\
$\begin{array}{l}\text { Fundulus heteroclitus } \\
\text { Pinfish }\end{array}$ & $<0.1$ & $<0.1$ & 0.1 & 0.1 & 14.8 & 19.2 \\
$\begin{array}{l}\text { Lagodon rhomboides } \\
\text { Spot }\end{array}$ & 63.8 & 208.2 & 2.7 & 2.2 & 5.5 & 36.9 \\
$\begin{array}{l}\text { Leiostomus xanthurus } \\
\text { Striped mullet }\end{array}$ & 0.2 & 0.3 & 0.0 & $<0.1$ & 0.5 & 1.6 \\
$\begin{array}{l}\text { Mugil cephalus } \\
\text { White mullet }\end{array}$ & $<0.1$ & 0.4 & 0.1 & 0.3 & 9.4 & 2.9 \\
$\begin{array}{l}\text { Mugil curema } \\
\text { White shrimp } \\
\text { Litopenaeus setiferus }\end{array}$ & 0.0 & 21.7 & 0.0 & 0.0 & 45.1 & 4.5 \\
& & & & & & \\
\hline
\end{tabular}




\section{RESULTS}

\section{Geomorphology}

Ranks based on values of each of the 28 physical variables indicated that although some creeks were more similar than others, no two were alike (Table 3).
Differences from 3- to 6-fold in the lengths, widths, cross-sectional areas of the mouths, volumes and total bottom areas were observed among creeks; however, these measurements of creek size were positively and significantly correlated (Table 4). The number of branches (tributaries) within the creeks was positively correlated with length but not with other size vari-

Table 3. Values and ranks of variables measured or derived from measurements at the 8 intertidal creeks. All variables are defined in Table 1. Following the variable name and abbreviation are: units of measurement (Unit), minimum (Min) and maximum (Max) values and the approximate multiplication factor (Factor) separating the minimum and maximum values. In the 8 columns on the right, the rank (1-8, with 1 representing the highest value) of each creek is shown for each variable

\begin{tabular}{|c|c|c|c|c|c|c|c|c|c|c|c|c|}
\hline \multirow{2}{*}{ Variable } & \multirow{2}{*}{ Unit } & \multirow{2}{*}{ Min } & \multirow{2}{*}{ Max } & \multirow{2}{*}{ Factor } & \multicolumn{8}{|c|}{ - Creek- } \\
\hline & & & & & 1 & 2 & 3 & 4 & 5 & 6 & 7 & 8 \\
\hline Length & $\mathrm{m}$ & 153 & 517 & 3 & 2 & 7 & 5 & 6 & 8 & 4 & 3 & 1 \\
\hline Width & $\mathrm{m}$ & 3.1 & 9.5 & 3 & 2 & 5 & 4 & 7 & 6 & 8 & 3 & 1 \\
\hline Depth & $\mathrm{m}$ & 0.41 & 0.73 & 2 & 7 & 8 & 4 & 3 & 6 & 2 & 5 & 1 \\
\hline Cross-section & $\mathrm{m}^{2}$ & 2.5 & 5.7 & 2 & 2 & 5 & 4 & 7 & 7 & 6 & 3 & 1 \\
\hline Bottom area & $\mathrm{m}^{2}$ & 333 & 1216 & 4 & 4 & 8 & 2 & 5 & 7 & 6 & 3 & 1 \\
\hline Elevation & $\mathrm{m}$ & 0.8 & 1.15 & 1 & 4 & 1 & 8 & 5 & 2 & 3 & 7 & 6 \\
\hline Volume & $\mathrm{m}^{3}$ & 231 & 1423 & 6 & 1 & 7 & 3 & 4 & 6 & 5 & 2 & 1 \\
\hline Drainage area & $\mathrm{m}^{2}$ & 9800 & 21200 & 2 & 1 & 4 & 7 & 6 & 3 & 5 & 3 & 2 \\
\hline Location & $\mathrm{m}$ & 146 & 1201 & 8 & 7 & 8 & 5 & 6 & 3 & 2 & 1 & 4 \\
\hline Branches & no. & 1 & 6 & 6 & 1 & 3 & 2 & 3 & 4 & 1 & 1 & 2 \\
\hline Bends & no. & 3 & 14 & 5 & 2 & 4 & 5 & 5 & 2 & 3 & 6 & 1 \\
\hline Slope & regr. & 0.2 & 0.4 & 2 & 5 & 1 & 4 & 7 & 6 & 3 & 2 & 8 \\
\hline Roughness & $\%$ & 22 & 46 & 2 & 5 & 7 & 4 & 2 & 6 & 8 & 1 & 3 \\
\hline Pools & no. & 1 & 7 & 7 & 1 & 4 & 3 & 7 & 5 & 6 & 6 & 2 \\
\hline Submerged area & $\mathrm{m}^{2}$ & 54 & 390 & 7 & 4 & 6 & 7 & 2 & 8 & 3 & 5 & 1 \\
\hline Oyster area & $\mathrm{m}^{2}$ & 78 & 280 & 4 & 1 & 2 & 7 & 8 & 5 & 6 & 4 & 3 \\
\hline Mud area & $\mathrm{m}^{2}$ & 57 & 942 & 17 & 6 & 8 & 2 & 3 & 7 & 5 & 4 & 1 \\
\hline Outside oyster area & $\mathrm{m}^{2}$ & 0 & 91 & & 1 & 4 & 7 & 6 & 3 & 8 & 5 & 2 \\
\hline Percent submerged bottom & $\%$ & 12 & 61 & 5 & 4 & 3 & 7 & 1 & 6 & 2 & 5 & 3 \\
\hline Percent oyster bottom & $\%$ & 14 & 83 & 6 & 2 & 1 & 7 & 7 & 3 & 5 & 4 & 6 \\
\hline Percent outside oysters & $\%$ & 0 & 82 & & 3 & 4 & 7 & 6 & 1 & 8 & 5 & 2 \\
\hline Conduit & ratio & 14.7 & 46.6 & 3 & 3 & 2 & 8 & 6 & 1 & 4 & 5 & 7 \\
\hline Axial dominance & ratio & 0.5 & 0.9 & 2 & 7 & 4 & 5 & 1 & 1 & 3 & 6 & 2 \\
\hline Steepness & ratio & 0.7 & 1.3 & 2 & 4 & 8 & 7 & 6 & 1 & 3 & 5 & 2 \\
\hline Fringe & ratio & 1.5 & 2.3 & 2 & 1 & 3 & 6 & 4 & 2 & 8 & 5 & 7 \\
\hline Flow & ratio & 0.004 & 0.014 & 4 & 3 & 1 & 2 & 5 & 4 & 5 & 3 & 6 \\
\hline Meander & ratio & 0.007 & 0.034 & 5 & 1 & 4 & 3 & 5 & 6 & 2 & 1 & 5 \\
\hline Split & ratio & 0.02 & 0.07 & 4 & 2 & 3 & 6 & 7 & 1 & 5 & 7 & 4 \\
\hline
\end{tabular}

Table 4. Relationships among 12 geomorphological features in the 8 creeks based on Spearman's correlation analyses. The $r$ values shown are significant at the $p<0.05$ level. NS: relationships that were not significant. All variables are defined in Table 1

\begin{tabular}{|c|c|c|c|c|c|c|c|c|c|c|c|c|}
\hline & Length & Width & Depth & $\begin{array}{c}\text { Cross } \\
\text { section }\end{array}$ & $\begin{array}{l}\text { Bottom } \\
\text { area }\end{array}$ & Elevation & Volume & Branches & $\begin{array}{l}\text { Mud } \\
\text { area }\end{array}$ & $\begin{array}{c}\% \text { Oyster } \\
\text { area }\end{array}$ & Steepness & Flow \\
\hline Length & - & & & & & & & & & & & \\
\hline Width & NS & & & & & & & & & & & \\
\hline Depth & NS & NS & - & & & & & & & & & \\
\hline Cross section & 0.86 & 0.92 & NS & - & & & & & & & & \\
\hline Bottom area & 0.76 & 0.71 & NS & 0.72 & - & & & & & & & \\
\hline Elevation & NS & NS & NS & NS & -0.91 & - & & & & & & \\
\hline Volume & 0.92 & 0.78 & NS & 0.81 & 0.91 & -0.71 & - & & & & & \\
\hline Branches & 0.78 & NS & NS & NS & NS & NS & NS & - & & & & \\
\hline Mud area & NS & NS & 0.81 & NS & 0.88 & -0.86 & NS & NS & - & & & \\
\hline \% Oyster area & NS & NS & -0.81 & NS & NS & NS & NS & NS & -0.86 & - & & \\
\hline Steepness & NS & NS & NS & NS & NS & NS & NS & NS & NS & NS & - & \\
\hline Flow & NS & NS & -0.81 & NS & NS & NS & NS & NS & NS & NS & NS & - \\
\hline
\end{tabular}


Table 5. Variable loading and percentage of the variance explained in the principal components analysis of geomorphological variables from the intertidal creeks. Column headings represent the first 6 principal components. Variables underlined are those with the highest loading values

\begin{tabular}{|c|c|c|c|c|c|c|}
\hline \multirow[t]{2}{*}{ Variable } & \multicolumn{6}{|c|}{ Principal components } \\
\hline & 1 & 2 & 3 & 4 & 5 & 6 \\
\hline Length & 0.67 & 0.41 & 0.32 & 0.36 & -0.35 & 0.16 \\
\hline Width & $\underline{0.76}$ & 0.61 & -0.16 & 0.08 & 0.12 & 0.04 \\
\hline Depth & $\overline{0.31}$ & -0.11 & $\underline{0.85}$ & 0.08 & -0.22 & 0.33 \\
\hline Cross-section & 0.74 & 0.46 & -0.08 & 0.45 & 0.16 & -0.03 \\
\hline Bottom area & $\underline{0.83}$ & 0.36 & 0.24 & -0.01 & -0.27 & 0.15 \\
\hline Elevation & $-\underline{0.91}$ & 0.29 & -0.15 & -0.14 & -0.21 & 0.00 \\
\hline Volume & 0.68 & 0.53 & 0.38 & 0.01 & -0.24 & 0.23 \\
\hline Drainage area & 0.02 & $\underline{0.92}$ & 0.08 & 0.28 & -0.09 & 0.12 \\
\hline Location & 0.03 & -0.28 & 0.58 & 0.01 & 0.18 & $\underline{0.73}$ \\
\hline Branches & 0.20 & 0.02 & 0.17 & $\underline{0.94}$ & -0.05 & 0.18 \\
\hline Bends & -0.06 & $\underline{0.88}$ & 0.29 & -0.10 & -0.18 & 0.10 \\
\hline Slope & -0.30 & -0.13 & $-\underline{0.90}$ & 0.14 & 0.07 & 0.26 \\
\hline Roughness & $\underline{0.81}$ & -0.07 & 0.01 & -0.08 & 0.14 & -0.22 \\
\hline Pools & 0.24 & 0.74 & 0.00 & 0.38 & 0.18 & -0.40 \\
\hline Submerged area & 0.44 & 0.16 & 0.27 & -0.22 & $-\underline{0.80}$ & 0.04 \\
\hline Oyster area & 0.14 & $\underline{0.81}$ & -0.51 & 0.23 & -0.11 & 0.07 \\
\hline Mud area & $\underline{0.83}$ & 0.11 & 0.43 & -0.09 & -0.25 & 0.14 \\
\hline Outside oyster area & 0.06 & $\underline{0.87}$ & -0.16 & -0.03 & 0.12 & -0.39 \\
\hline \% Subm. bottom & -0.16 & -0.23 & 0.10 & -0.17 & $-\underline{0.91}$ & -0.10 \\
\hline \% Oyster bottom & -0.46 & 0.42 & $-\underline{0.78}$ & 0.05 & 0.05 & 0.01 \\
\hline$\%$ Outside oyster & 0.03 & $\underline{0.85}$ & 0.03 & -0.40 & 0.26 & 0.00 \\
\hline Conduit & $-\underline{0.87}$ & 0.34 & -0.25 & -0.03 & 0.23 & 0.04 \\
\hline Axial dominance & -0.16 & -0.04 & 0.54 & $-\underline{0.74}$ & -0.32 & 0.17 \\
\hline Steepness & -0.19 & 0.47 & $\underline{0.76}$ & 0.04 & 0.18 & 0.24 \\
\hline Fringe & -0.52 & 0.38 & 0.08 & 0.72 & 0.04 & -0.23 \\
\hline Flow & -0.18 & -0.06 & $-\underline{0.92}$ & 0.11 & 0.26 & -0.13 \\
\hline Meander & -0.01 & -0.12 & -0.25 & $\underline{0.92}$ & 0.23 & -0.02 \\
\hline Split & -0.50 & 0.66 & 0.09 & -0.21 & 0.42 & 0.25 \\
\hline$\%$ Variance & 25.10 & 24.60 & 19.10 & 13.50 & 9.30 & 5.30 \\
\hline
\end{tabular}

\section{Nekton}

ANOVA showed that season had a significant effect on nekton, biomass and species richness $(\mathrm{p}<0.05)$. Total nekton biomass was not significantly different in March, June and November $(\mathrm{p}<0.05)$. Biomass in August was significantly higher $(p<0.05)$, but not distinguishable from June (Fig. 2). Total abundances were similar in March, June and August. Abundance was significantly lower $(p<0.1)$ in November, but could not be distinguished from levels in June. High levels of species richness occurred in June and August (Fig. 2). Richness levels were similar $(p<0.05)$ in March and November, but both were significantly lower than in the summer months.

Seasonal and spatial patterns of occurrence were stronger than interannual patterns for total nekton and most individual taxa (Table 2). Within seasons, total abundance among creeks varied by 4 to 28 times and total biomass varied by 3 to 25 times (Fig. 2). Among seasons, the same creeks had consistently higher or lower biomasses than others (Table 6). Biomass in Creek 2 was ranked highest or second highest during all 8 sam-

ables. Creek size was not related to either drainage area or the distance between the creek mouth and the nearest upland edge (location).

Negative relationships between the elevation of the mouth and both volume and bottom area indicated that smaller creeks tended to be perched higher in the tidal range where they started flooding later and finished ebbing earlier in the tidal cycle (Table 4). Depth was not correlated with the elevation of the mouth or with other size variables. Creeks with shallow mean depth and greater slope filled and drained more slowly than others. Deep creeks had larger areas of mud bottom

Results of the principal component analyses using all 28 physical variables indicated that creeks differed in shape, size and relationships with external features (Table 5). In the first principal component, the 4 variables with highest loadings were elevation, conduit, mud bottom area and roughness. Drainage area, bends, depth, slope, flow, branches and percent bottom submerged had the highest loading values among the other components. Together, the 6 principal components explained about $96 \%$ of the overall variance. plings (Fig. 2, Table 6). Creeks 3, 4 and 1 were ranked higher than most other creeks during the 2 yr period. Creek 6 biomass was lowest and Creek 8 ranked last or next to last on almost every date. As a group, Town Creek locations (5 to 8) ranked lower than Clambank Creek locations (1 to 4 ) on all dates.

At least 77 species of fishes and motile epibenthic crustaceans were collected during the study. Overall, 11 taxa accounted for $>93 \%$ of the biomass and $>99 \%$ of the abundance. Within seasons, the same group of taxa dominated in all creeks (Fig. 3) Grass shrimp Palaemonetes spp. (with $P$. pugio, 21 to $43 \mathrm{~mm}$, accounting for $>90 \%$ ) was by far the most abundant overall and during each season; it was the only taxon represented in every collection and its abundance exceeded the abundances of all other taxa in $83 \%$ of the collections (Table 7). Composition varied considerably among seasons, but composition by season was similar among years (Fig. 4). In March, resident taxa including grass shrimp Palaemonetes spp, mummichog Fundulus heteroclitus (24 to $98 \mathrm{~mm}$ ) and Atlantic silverside Menidia menidia (74 to $103 \mathrm{~mm}$ ) accounted 

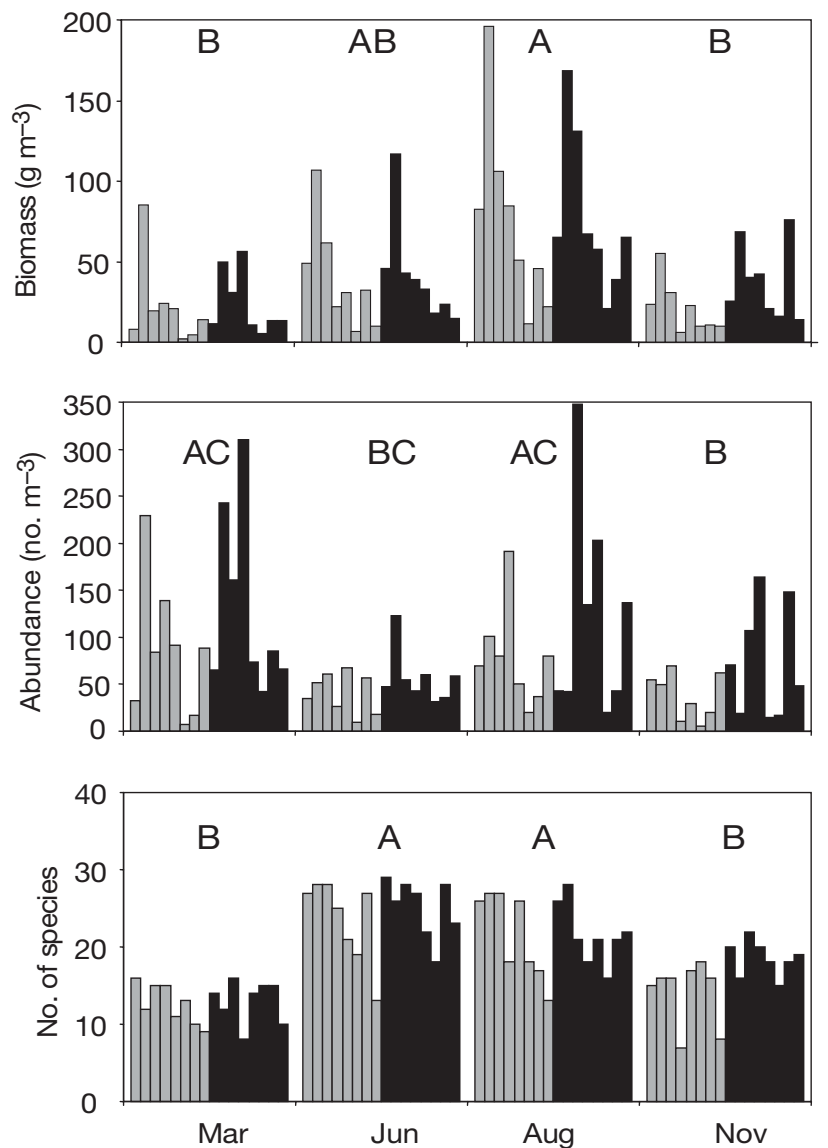

Fig. 2. Biomass, abundance and species richness for 8 intertidal creeks during the March, June, August and November collections in 1997 and 1998. Each bar represents one creek and the 8 creeks are shown in order (1-8). The 1997 (grey bars) and 1998 (black bars) data are paired for each month to facilitate comparison within and between months. Results of post hoc Tukey tests (both years combined, $\log (n+1)$ transformed data) comparing months are shown with shared letters indicating no differences. The significance level for the ANOVA was $p<0.05$ and, for the Tukey tests, they were $p<0.05$ for biomass and species richness and $\mathrm{p}<0.1$ for abundance

Table 6. Ranks for total nekton biomass densities $\left(\mathrm{g} \mathrm{m}^{-3}\right)$ at the 8 creeks during the quarterly samplings. A rank of 1 indicates the location with the highest value for that sampling period

\begin{tabular}{|rrrrrrrrr|}
\hline & \multicolumn{7}{c}{ Creek } \\
& 1 & 2 & 3 & 4 & 5 & 6 & 7 & 8 \\
\hline Mar 1997 & 6 & 1 & 4 & 2 & 3 & 8 & 7 & 5 \\
1998 & 6 & 2 & 3 & 1 & 7 & 8 & 4 & 5 \\
Jun 1997 & 3 & 1 & 2 & 6 & 5 & 8 & 4 & 7 \\
1998 & 2 & 1 & 3 & 4 & 5 & 7 & 6 & 8 \\
Aug 1997 & 4 & 1 & 2 & 3 & 5 & 8 & 6 & 7 \\
1998 & 5 & 1 & 2 & 3 & 6 & 8 & 7 & 3 \\
Nov 1997 & 3 & 1 & 2 & 8 & 5 & 7 & 4 & 6 \\
1998 & 5 & 2 & 4 & 3 & 6 & 7 & 1 & 8 \\
\hline
\end{tabular}

for the greatest portion of total abundance and biomass. Young of the year spot Leiostomus xanthurus (23 to $33 \mathrm{~mm}$ ) made up most of the rest of the March catches; more spot occupied the creeks in 1998. In June, grass shrimp and mummichog together accounted for the highest portion of the total abundance with spot and anchovy Anchoa spp. (35 to $66 \mathrm{~mm}$ ) accounting for most of the rest. However, June total biomass was more evenly distributed between these abundant, small taxa and less numerous, larger taxa such as blue crab Callinectes sapidus (35 to $166 \mathrm{~mm}$ ), pinfish Lagodon rhomboides (65 to $160 \mathrm{~mm}$ ), striped mullet Mugil cephalus (67 to $320 \mathrm{~mm}$ ) and white mullet $M$. curema (41 to $70 \mathrm{~mm}$ ). In August, white shrimp Litopenaeus setiferus (42 to $122 \mathrm{~mm}$ ) and anchovy contributed to higher transient than resident species biomass. In November, grass shrimp was again the most abundant with Atlantic silverside, anchovy and mummichog accounting for most of the rest of the catch. November biomass was dominated by resident taxa.
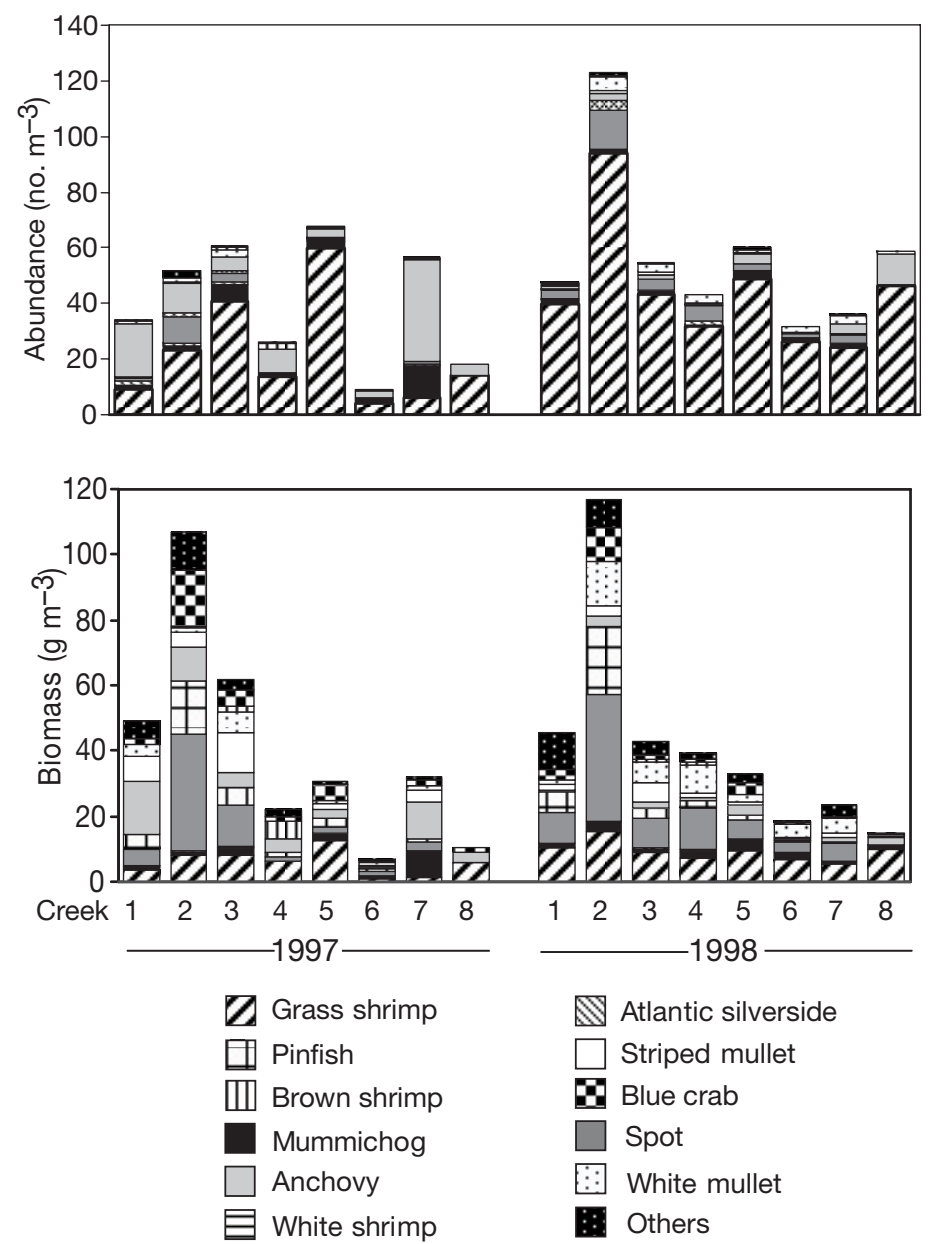

Fig. 3. Abundance and biomass densities for 11 dominant taxa and others in each of the 8 creeks during June 1997 and 1998 
Table 7. Summary of abundance density statistics for total nekton and the top 11 taxa in the intertidal creeks. Values are given for percent occurrence in all collections (Freq), peak abundance (Peak) and mean abundance with SE (parentheses) for each of the 4 mo (yr combined)

\begin{tabular}{|c|c|c|c|c|c|c|}
\hline \multirow[t]{2}{*}{ Taxon } & \multirow{2}{*}{$\begin{array}{l}\text { Freq } \\
(\%)\end{array}$} & \multirow{2}{*}{$\begin{array}{c}\text { Peak } \\
\left(\text { no. } \mathrm{m}^{-3}\right)\end{array}$} & \multicolumn{4}{|c|}{ Mean abundance (no. $\mathrm{m}^{-3}$ ) } \\
\hline & & & Mar & Jun & Aug & Nov \\
\hline Total nekton & 100 & 347.6 & $\begin{array}{l}108.4 \\
(21.6)\end{array}$ & $\begin{array}{l}48.7 \\
(6.5)\end{array}$ & $\begin{array}{c}99.9 \\
(21.8)\end{array}$ & $\begin{array}{c}55.4 \\
(12.0)\end{array}$ \\
\hline $\begin{array}{l}\text { Grass shrimp } \\
\text { Palaemonetes spp. }\end{array}$ & 100 & 291.3 & $\begin{array}{c}69.0 \\
(13.9)\end{array}$ & $\begin{array}{l}32.7 \\
(5.9)\end{array}$ & $\begin{array}{c}63.0 \\
(19.3)\end{array}$ & $\begin{array}{c}42.8 \\
(10.6)\end{array}$ \\
\hline $\begin{array}{l}\text { Mummichog } \\
\text { Fundulus heteroclitus }\end{array}$ & 98 & 11.8 & $\begin{array}{c}0.3 \\
(<0.1)\end{array}$ & $\begin{array}{c}2.2 \\
(0.7)\end{array}$ & $\begin{array}{l}2.3 \\
(0.5)\end{array}$ & $\begin{array}{c}1.3 \\
(0.4)\end{array}$ \\
\hline $\begin{array}{l}\text { Spot } \\
\text { Leiostomus xanthurus }\end{array}$ & 95 & 177.3 & $\begin{array}{c}35.6 \\
(12.0)\end{array}$ & $\begin{array}{c}3.1 \\
(0.9)\end{array}$ & $\begin{array}{l}1.0 \\
(0.5)\end{array}$ & $\begin{array}{c}0.1 \\
(<0.1)\end{array}$ \\
\hline $\begin{array}{l}\text { Pinfish } \\
\text { Lagodon rhomboides }\end{array}$ & 94 & 6.6 & $\begin{array}{c}0.2 \\
(<0.1)\end{array}$ & $\begin{array}{c}0.6 \\
(0.2)\end{array}$ & $\begin{array}{c}0.6 \\
(0.2)\end{array}$ & $\begin{array}{c}0.1 \\
(<0.1)\end{array}$ \\
\hline $\begin{array}{l}\text { Brown shrimp } \\
\text { Farfantepenaeus aztecus }\end{array}$ & 25 & 1.9 & 0 & $\begin{array}{l}<0.2 \\
(<0.1)\end{array}$ & 0 & 0 \\
\hline $\begin{array}{l}\text { White shrimp } \\
\text { Litopenaeus setiferus }\end{array}$ & 50 & 164.9 & 0 & 0 & $\begin{array}{c}17.2 \\
(10.0)\end{array}$ & $\begin{array}{c}4.1 \\
(3.8)\end{array}$ \\
\hline $\begin{array}{l}\text { White mullet } \\
\text { Mugil curema }\end{array}$ & 77 & 5.0 & $<0.1$ & $\begin{array}{l}1.5 \\
(0.3)\end{array}$ & $\begin{array}{c}1.0 \\
(0.3)\end{array}$ & $<0.1$ \\
\hline $\begin{array}{l}\text { Striped mullet } \\
\text { Mugil cephalus }\end{array}$ & 74 & 10.9 & $\begin{array}{l}1.7 \\
(0.9)\end{array}$ & $\begin{array}{c}0.2 \\
(<0.1)\end{array}$ & $\begin{array}{c}0.3 \\
(0.1)\end{array}$ & $<0.1$ \\
\hline $\begin{array}{l}\text { Anchovies } \\
\text { Anchoa spp. }\end{array}$ & 98 & 47.3 & $\begin{array}{c}0.9 \\
(0.4)\end{array}$ & $\begin{array}{l}7.1 \\
(2.3)\end{array}$ & $\begin{array}{l}12.2 \\
(3.6)\end{array}$ & $\begin{array}{l}3.3 \\
(2.5)\end{array}$ \\
\hline $\begin{array}{l}\text { Atlantic silverside } \\
\text { Menidia menidia }\end{array}$ & 91 & 12.3 & $\begin{array}{c}0.5 \\
(0.2)\end{array}$ & $\begin{array}{c}0.5 \\
(0.1)\end{array}$ & $\begin{array}{c}1.6 \\
(0.8)\end{array}$ & $\begin{array}{c}3.4 \\
(0.9)\end{array}$ \\
\hline $\begin{array}{l}\text { Blue crab } \\
\text { Callinectes sapidus }\end{array}$ & 86 & 0.5 & $<0.1$ & 0.1 & 0.1 & $<0.1$ \\
\hline
\end{tabular}

strongly correlated with the first canonical axis of the multivariate nekton dataset (Table 8).

The analyses for mummichog yielded a significant first canonical correlation only in June $\left(\mathrm{r}^{2}=0.94\right)$ when $94 \%$ of the variance was explained (Table 8). Abundance was more completely explained by the geomorphological variables than was biomass. Percent of the creek bottom remaining submerged at low tide $(-0.75)$ was by far the most important variable, but flow (0.47) and depth $(-0.45)$ were also important factors.

For spot, significant first canonical correlations were found in August $\left(\mathrm{r}^{2}=\right.$ 0.93 ) and November $\left(r^{2}=0.97\right)$, when $83 \%$ and $97 \%$ of the overall variance was explained, respectively (Table 8). In August, location (-0.73) and depth $(-0.71)$ and in November, flow (0.87) and depth (-0.84) were the most important factors. Six other factors were more important in August than November.

Analyses of pinfish data demonstrated significant first canonical correlations for 3 seasons. The proportion of the overall variance explained in each analysis was high and both the biomass and abundance were highly

\section{Relationships between nekton and geomorphological features}

The first canonical correlation linking the nekton and geomorphological variables was highly significant $(\mathrm{p}<0.01)$ for total nekton abundance and biomass and species richness. In June, the first canonical correlation value $\left(r^{2}=0.97\right)$ explained $86 \%$ of the variance, and in August, it $\left(\mathrm{r}^{2}=0.96\right)$ explained $77 \%$ (Table 8$)$. In both seasons, biomass was explained better than richness or abundance. In June, flow (0.86), depth $(-0.76)$, steepness $(-0.74)$ and location $(-0.69)$ were the geomorphological values most strongly correlated with the first canonical axis. These same 4 variables were also the most strongly correlated with total nekton in August.

For grass shrimp, March was the only season for which a significant first canonical correlation was determined $\left(\mathrm{r}^{2}=0.97\right)$. In the analysis, $99 \%$ of the overall variance was explained and abundance and biomass were equally highly correlated to the first canonical axis of the geomorphological variables. Branches $(-0.80)$, location $(-0.69)$, meander $(-0.62)$ and length $(-0.55)$ were the geomorphological variables most correlated with the geomorphological variables in the first canonical correlation (Table 8). In June $\left(\mathrm{r}^{2}=0.98\right.$, $98 \%)$, the most important factors were depth $(-0.82)$, flow (0.81), location $(-0.76)$ and steepness $(-0.58)$. In August $\left(\mathrm{r}^{2}=0.94,88 \%\right)$, depth $(-0.77)$ was the most important factor and location, length, total bottom area, also strongly correlated. In November $\left(\mathrm{r}^{2}=0.95,96 \%\right)$, depth $(-0.77)$ and flow (0.76) were again the most important, with length, volume, total bottom area, conduit and elevation being additional strong variables.

Brown shrimp Farfantepenaeus aztecus results (not shown) for June $\left(\mathrm{r}^{2}=0.92,91 \%\right)$ showed steepness $(-0.81)$ was the most important factor, whereas white shrimp results (not shown) for August $\left(\mathrm{r}^{2}=0.94,95 \%\right)$ showed that bends $(-0.77)$ and steepness (-0.75) ranked highest. Biomass and abundance variations were explained well in the analyses for both penaeid shrimps.

For striped mullet (results not shown) in June $\left(\mathrm{r}^{2}=\right.$ 0.93), $97 \%$ of the overall variance was explained and biomass was more completely addressed than abundance. Catches were strongly related to flow (0.89) flow, branches, conduit, elevation and volume were 


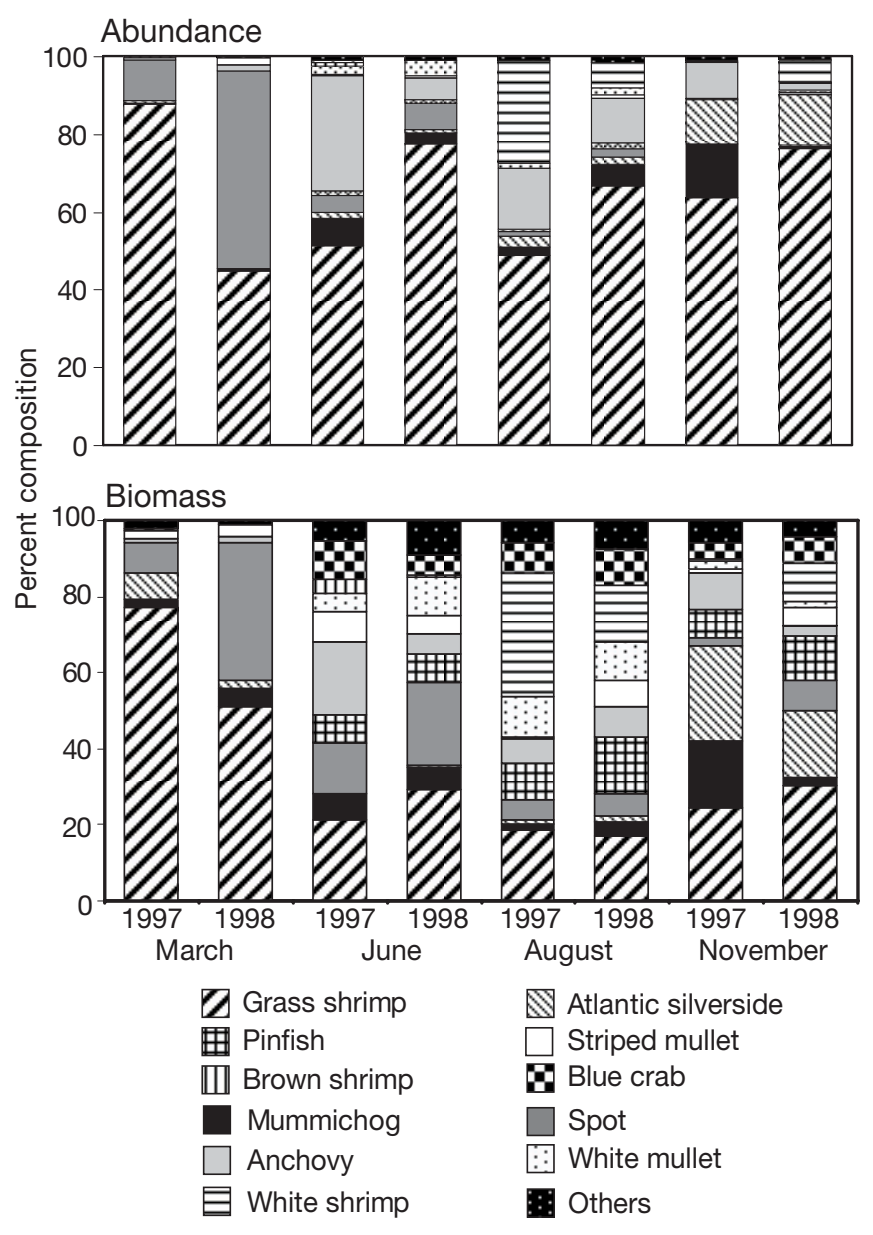

Fig. 4. Percent of total abundance and biomass represented by the 11 dominant taxa and others (all other taxa combined) during each of the sampling periods. Density data from all 8 creeks were used to determine each seasonal value

with depth $(-0.67)$, axial dominance $(-0.64)$, percent submerged bottom area (-0.60), slope (0.56) and steepness $(-0.56)$ being additional strong factors.

For Atlantic silverside in November $\left(\mathrm{r}^{2}=0.96\right), 83 \%$ of the overall variance was explained but neither biomass nor abundance were well accounted for in the analyses. No correlation of a variable to the first canonical axis of the nekton variables exceeded 0.5. No significant first canonical correlations were found for white mullet, anchovy, or blue crab.

Overall, among the 21 geomorphological variables used in the canonical correlation analyses, 4 physical variables were most important. Flow and depth were the physical features that most strongly correlated with total nekton, mummichog, spot, pinfish and striped mullet. Location and steepness were the next most important features for total nekton as well as for spot, pinfish and brown shrimp. One or more of these 4 factors was among the most important factors for each of the 11 dominant taxa. Only 2 variables, pools and percent oyster area, were not correlated with total nekton or individual taxa.

The signs or directions of the relationships differed among variables. For taxa in which flow, elevation of the mouth and slope were important factors, positive relationships were indicated (Table 8). Depth, steepness, location, drainage area, bends, meander, branches, splits, length, axial dominance, volume, roughness, total bottom area and percent submerged bottom area were all inversely related to density in analyses in which they were strongly correlated factors.

Rankings of the variables identified as most important to individual species in the CANCOOR analyses were similar to those for the same features among the set of 8 creeks (Table 3). For example, in March, grass shrimp (which were inversely correlated to branches) were least abundant in Creek 6, which had higher numbers of branches than most other creeks. Grass shrimp were inversely correlated to location (distance to upland ridge) and were most abundant in Creek 2, which was closest to the uplands. Location and depth were among the most important factors (negative correlations) for spot and pinfish and their densities were highest in shallow creeks closest to the uplands. The biomass and abundance of both spot and pinfish increased as flow decreased.

\section{DISCUSSION}

Recurring patterns and large differences in the magnitude of nekton use among intertidal creeks, combined with evidence of strong relationships between nekton densities and certain hydrogeomorphological features, indicated that selection for favorable conditions played an important role in the distribution of nekton. Because use was not related to the size of the creeks (length, width, bottom area, or volume) and the smallest, slowest flowing creeks supported the highest densities, large inter-creek differences in nekton use could not be explained by passive transport of nekton from low tide refuges in adjacent subtidal channels. Spatial differences were most likely the result of directed movements caused by behavioral responses to certain physical attributes of the creeks. Selection is the non-random use of space resulting from voluntary movements (Kramer et al. 1997) and a mechanism by which choices are made among alternatives (Craig \& Crowder 2000). Many tagging and telemetry studies have demonstrated that individual fishes regularly return to or remain in certain locations. Some rocky intertidal pool fishes are able to learn the topography of their environment and return repeatedly to the same locations (Gibson 1999). High site fidelity or extended 
Table 8. Results of the canonical correlation analyses for total catch, mummichog, grass shrimp, spot and pinfish. Indicators of the strength of the overall analysis are given for months in which there was a significant relationship between biomass, abundance and/or species richness and geomorphological features. All canonical correlation numbers: I

\begin{tabular}{|c|c|c|c|c|c|c|c|c|c|}
\hline \multirow[b]{2}{*}{ Month } & \multicolumn{2}{|c|}{$\begin{array}{l}\text { Total } \\
\text { catch }\end{array}$} & \multirow{2}{*}{$\begin{array}{l}\text { Grass shrimp } \\
\text { Palaemonetes } \\
\text { spp. } \\
\text { Mar }\end{array}$} & \multirow{2}{*}{$\begin{array}{c}\text { Mummichog } \\
\text { Fundulus } \\
\text { heteroclitus }\end{array}$} & \multicolumn{2}{|c|}{$\begin{array}{c}\text { Spot } \\
\text { Leiostomus } \\
\text { xanthurus }\end{array}$} & \multicolumn{3}{|c|}{$\begin{array}{c}\text { Pinfish } \\
\text { Lagodon } \\
\text { rhomboides }\end{array}$} \\
\hline & Jun & Aug & & & Aug & Nov & Jun & Aug & Nov \\
\hline $\mathrm{r}^{2}$ & 0.97 & 0.96 & 0.97 & 0.94 & 0.93 & 0.97 & 0.98 & 0.94 & 0.95 \\
\hline $\operatorname{pr}>F$ & 0.0051 & 0.0049 & 0.0091 & 0.0434 & 0.0154 & 0.0035 & 0.0038 & 0.0271 & 0.0247 \\
\hline$\%$ Variance explained & 86 & 77 & 99 & 94 & 83 & 97 & 98 & 88 & 96 \\
\hline \multicolumn{10}{|l|}{ Criterion: } \\
\hline Biomass & 0.93 & 0.95 & 0.96 & 0.46 & 0.93 & 0.71 & 0.97 & 0.93 & 0.81 \\
\hline Abundance & 0.35 & 0.37 & 0.97 & 0.94 & 0.92 & 0.87 & 0.93 & 0.90 & 0.92 \\
\hline Species richness & 0.82 & 0.67 & & & & & & & \\
\hline \multicolumn{10}{|l|}{ Predictor: } \\
\hline Flow & 0.86 & 0.69 & & 0.47 & 0.60 & 0.87 & 0.81 & 0.58 & 0.76 \\
\hline Depth & -0.76 & -0.54 & & -0.45 & -0.71 & -0.84 & -0.82 & -0.77 & -0.77 \\
\hline Steepness & -0.74 & -0.81 & & 0.08 & -0.39 & -0.45 & -0.58 & -0.34 & -0.37 \\
\hline Location & -0.69 & -0.82 & -0.69 & 0.37 & -0.73 & -0.58 & -0.76 & -0.69 & -0.47 \\
\hline Slope & 0.44 & 0.26 & -0.14 & 0.38 & & & & & \\
\hline$\%$ Oyster bottom & 0.35 & 0.14 & & & 0.54 & 0.54 & & & \\
\hline Meander & 0.33 & -0.05 & -0.62 & & & & & & \\
\hline$\%$ Submerged bottom & -0.30 & -0.09 & & -0.75 & & & & & \\
\hline Fringe & 0.26 & -0.06 & -0.41 & & & & & & \\
\hline Length & -0.24 & -0.37 & -0.55 & -0.16 & & & -0.46 & -0.63 & -0.63 \\
\hline Branches & -0.05 & -0.37 & -0.80 & & & & -0.30 & -0.58 & -0.33 \\
\hline Elevation & 0.04 & 0.09 & 0.23 & -0.12 & 0.58 & 0.26 & 0.32 & 0.55 & 0.48 \\
\hline Conduit & & & -0.02 & & 0.52 & 0.38 & 0.36 & 0.56 & 0.53 \\
\hline Volume & & & & -0.07 & & & -0.37 & -0.53 & -0.62 \\
\hline Bends & & & & -0.29 & & & & & \\
\hline Bottom area & & & & -0.05 & -0.59 & -0.32 & -0.40 & -0.60 & -0.59 \\
\hline Roughness & & & & 0.01 & -0.58 & -0.32 & & & \\
\hline Cross section & & & & & & & -0.11 & -0.33 & -0.32 \\
\hline Drainage area & & & & & & & -0.10 & -0.02 & -0.19 \\
\hline
\end{tabular}

periods of residency have been demonstrated for several estuarine species (Lotrich 1975, Weinstein \& O'Neil 1986). Potthoff \& Allen (2003) showed that tagged juvenile pinfish moved between intertidal creeks and the adjacent subtidal channel, but not into neighboring intertidal creeks. Stability in spatial patterns of nekton use among creeks over long periods is best explained by the ability of individuals to recognize features and return to specific locations.

Mechanisms by which unequal spatial distributions of nekton are established and maintained are difficult to elucidate and few investigators have addressed the subject (Craig \& Crowder 2000). One possibility is that over periods of days and weeks, highly motile individuals visit multiple creeks and select one that they will repeatedly reenter. If some creeks are more attractive and can support higher densities than others, unequal levels of use would result. When densities of regular users approach the carrying capacity of the habitat, other individuals might be expected to use other creeks or habitats that have less suitable conditions. The Ideal Free Distribution model (Fretwell 1972) pre- dicts that density in each habitat (e.g intertidal creek) will be positively correlated with its intrinsic suitability, some habitats attracting and supporting higher densities than others (Kramer \& Chapman 1999). Evidence of persistent differences in nekton use of adjacent estuarine creeks has also been reported by Paterson \& Whitfield (2003).

Of the 28 variables used in the analyses, flow (cross sectional area:volume) was the factor that affected nekton biomass and abundance more often than any other. Total nekton, spot, pinfish, mummichogs, white shrimp and striped mullet might have been attracted to slow flowing creeks or they actively avoided creeks in which flow was stronger. Cattrijesse et al. (1994) found that nekton in an intertidal creek in the Netherlands migrated at the beginning and end of the tide when current velocities were lowest. McIvor \& Rozas (1996) reported higher abundances with lower flow.

Shallow depth was one of the 4 most important factors. Creeks with shallower mean depths were not necessarily perched higher in the tidal range, however, shallow creeks flooded and emptied more slowly. Shal- 
low depths may be attractive to small nekton as refuge from aquatic predators, but Craig \& Crowder (2000) concluded that few studies have directly tested this. Using tethering experiments, Ruiz et al. (1993) demonstrated higher mortality of grass shrimps, mummichogs and other small fishes with increasing depth. Large predators were uncommon in flooded intertidal creeks, but they occurred in adjacent subtidal channels (Cain \& Dean 1976, Paterson \& Whitfield 2003, Bretsch \& Allen 2006). Nekton may select shallow depths to find more abundant or preferred prey resources (Kneib 1997).

Steepness was another important feature with low steepness supporting higher nekton use. Creeks with more gently sloped banks had slower flow. This was also reported by McIvor \& Odum (1988). We would expect that intertidal creeks with flatter profiles are used more by demersal foragers than creeks with nearly vertical, eroding marsh banks. Low bank steepness was the most important factor affecting brown shrimp in June and white shrimp in August, when they were at peak abundances. Rozas \& Zimmerman (2000) found both brown and white shrimps most abundant at low, shoreline marsh sites, and Wenner \& Beatty (1993) recognized the importance of sloped intertidal creek (rivulet) banks to juvenile white shrimp. For some species, gently sloped edges may provide better refuges than steep banks (McIvor \& Odum 1988, Hettler 1989). Rozas et al. (1988) concluded that depositional (sloped) creek banks were the primary corridors for nekton movements between creeks and the marsh surface. Many fishes were more abundant in California salt marsh creeks with sloped than steep banks (Williams \& Zedler 1999).

The length of marsh edge was not an important factor for nekton use of intertidal creeks. Nekton densities in other systems are higher at marsh edges than on adjacent open bottom or interior marshes (Baltz et al. 1993, Minello et al. 1994, Peterson \& Turner 1994, Cicchetti \& Diaz 2000, Minello et al. 2003). Edge habitat varies geographically with respect to landscape features such as channel network complexity, which increases with tidal range along the Atlantic coast (McIvor and Rozas 1996). Temporally dynamic relationships between edges and adjacent intertidal and subtidal areas also account for high variability in nekton use. Elevation of the bank, characteristics of the adjacent water body, proximity of vegetation to the edge and types and densities of plant stems are some factors that affect the use of edges (Rakocinski et al. 1992, Rozas \& Zimmerman 2000). Differences in the relationship between nekton and edges are expected between locations and the spatial and temporal scales of measurements. A significant $\mathrm{km}$ scale relationship was reported between densities of white shrimp occu- pying Georgia creeks near low tide and the amount of intertidal edge (Webb \& Kneib 2002). Kneib (2003) reported a strong relationship between production of nekton and the amount of intertidal edge. At the scale of the intertidal creek with whole creek collections being made at bank full high tide, our study indicated that amount of edge was not as important as other features including the slope of the bank (edge).

The association of higher nekton densities with nearness to an upland ridge (location) could not be attributed to differences in internal geomorphology or drainage area of the intertidal creeks, and salinity regimes did not vary among creeks. Dame et al. (1992) concluded that age related differences in physical and geochemical features of the marsh along the continuum from the uplands to the ocean ends of estuaries such as North Inlet may influence the distribution of estuarine species. Other studies have reported that nekton abundances increase with decreasing stream order and proximity to uplands (Rozas \& Odum 1987, Desmond et al. 2000, Webb \& Kneib 2002). Differences in nekton use between the 2 groups of intertidal creeks may have been related to differences in size, depth, or other characteristics of the adjacent subtidal channels that may have affected predator abundance or refuge availability at low tide.

Strong relationships between nekton and certain geomorphological characteristics suggest that major intertidal creeks serve as more than just corridors for nekton movement. Intertidal creeks are often thought of as conduits connecting permanently flooded and higher intertidal areas (Kneib 1997, Wenner \& Beatty 1993). Rozas et al. (1988) demonstrated that compared to edges bordering open water, small creeks (rivulets) were the primary corridors for nekton movements into a tidal marsh. Hettler (1989) reported densities were higher adjacent to a rivulet than adjacent to a major creek bank. McIvor \& Rozas (1996) concluded that the proximity of rivulets to the marsh enabled nekton to maximize time on the marsh and that rivulets afforded greater protection from predators. Because intertidal creeks are inundated for longer periods than the adjacent marsh, use by nekton is expected to be important regardless of whether those occupants eventually move onto the flooded marsh. We assumed the tidal migrants were not able to predict the extent to which they could access the marsh from tide to tide, so collections at bank full (20 to $30 \%$ of the tides) were representative of regular patterns of use. If so, selection for certain internal characteristics of creeks might be more important than features of the surrounding marsh. In fact, we found that use of the creeks by total nekton, all shrimps and most fishes was related to internal features but not to drainage area. The exceptions (blue crab, white mullet and striped mullet) were commonly 
observed foraging on the flooded marsh. Anchovies and Atlantic silversides, pelagic feeders that were abundant in creeks but not on the marsh, were not associated with drainage area and were only weakly influenced by internal features.

Grass shrimp, the overall most abundant tidal migrant every season, did not appear to be strongly influenced by the geomorphological characteristics of the creeks. It was only related to features in March when densities of overwintering shrimps were related to branches, meander and length. Few transient taxa were present in March. The absence of relationships during the warm months suggests that smaller summer generation grass shrimps were not as responsive to physical features when many other taxa co-occupied the creeks.

The importance of slow flow and shallow depth to the mummichog was consistent with other reports (Kneib 1997). The most important factor affecting their use was the proportion of bottom submerged at low tide. This inverse relationship might be explained by their preference for deeper areas of submerged bottom. In this area, creeks with lower percent submergence at low tide have deeper pools. The lack of relationships between mummichog (>15 mm) in creeks and the sizes of adjacent marsh basins during any season suggests that geomorphological differences within creeks (pools) may be more important than the amount of marsh available around high tide.

We did not find evidence that oysters provide essential habitat for nekton within intertidal creeks. Removal of live oysters in the BACI experiment did not affect patterns of use between years and bottom coverage by oyster shell was not an important feature for either total nekton or individual taxa in the multivariate analyses conducted for the $2 \mathrm{yr}$ period. These findings contrast with the results of many reports that identify Eastern oyster reefs as important nekton habitat (Dame 1996, Coen et al. 1999). This may be due to the differences in the configuration of oysters and tidal currents in intertidal creeks compared to those on subtidal reefs (Coen et al. 1999, Lehnert \& Allen 2002) or intertidal fringing and island reefs surrounded by open water or flats (Wenner et al. 1996, Glancy et al. 2003). Oysters in intertidal creeks tend to occur in small isolated patches and are not exposed to strong tidal currents and wave action. Other physical features of intertidal creeks appear to influence patterns of nekton use more strongly than the presence of oysters.

Our findings raise an interesting question about the relative importance of geomorphology and water quality to nekton use of tidal creeks. Spatial variations in the abundance of estuarine nekton are often attributed to variations in salinity, dissolved oxygen, or other water quality parameters. Demonstrated relationships between the physical configuration of habitat and nek- ton use among neighboring creeks with similar and stable salinity suggest caution is necessary in evaluating causes for differences in nekton use of habitat along environmental gradients, regardless of habitat type or geographic location.

It is important to recognize that the hydrology, landscape structure and ecology of marshes and associated creeks on different coasts vary considerably, and that the features found to be important to nekton in this system may not be as important as other features elsewhere. The approach to identifying geomorphological features of importance to nekton used in this study should be useful in other marsh, mangrove and shallow-water systems. Nevertheless, we believe that our finding that shallow average depths, broad lateral profiles, slow tidal flow and close proximity to uplands support the highest densities of nekton has broad applications and can provide guidance for resource managers charged with protecting and restoring salt marsh systems. Creeks with these characteristics should be assigned high priority for protection. Webb \& Kneib (2002) recommended a precautionary approach to making land-use decisions that would reduce the structural complexity of marshes and networks of creeks. As components of the intertidal landscape, tidal creeks should be configured to provide essential ecological services to resident and transient species (Desmond et al. 2000, Rozas \& Zimmerman 2000, Able et al. 2002). Williams \& Zedler (1999) suggested that future restoration projects should mimic natural marsh hydrogeomorphology and diversity more closely. The importance of dendritic tidal channel complexity, habitat matrix heterogeneity and other attributes of estuarine landscape structure is described by Simenstad et al. (2002). Additional investigations of relationships between geomorphological features of creeks, water quality and the behavior and production of nekton populations will be necessary to determine design and management criteria that achieve sustainable functional equivalency for created marshes in different geographic regions.

Acknowledgements. We thank the many dozens of students, staff and volunteers who assisted with the field collections, sample processing and data management during the study, especially: A. Blair, J. Brewster, B. Brost, C. Burdick, E. Bustic, B. Castellion, C. Corbett, C. DeFranco, R. Ellin, A. J. Erskine, R. Green, L.Gregory, K. Hudson, L. Humphries, J. Keesee, P. Kenny, B. King, E. Koepfler, W. Lanham, V. OgburnMatthews, M. Potthoff, J. Raphan, P. Schneider and others associated with the Marine Science Dept, Coastal Carolina University and Baruch Marine Field Laboratory, University of South Carolina. D. Aguilera and J. Blakely assisted with formatting the manuscript, and D. Edwards assisted with statistical analyses. This work was supported by NSF award DEB 950957 from 1996-2001. This manuscript is Belle W. Baruch Institute for Marine and Coastal Sciences contribution No. 1447. 


\section{LITERATURE CITED}

Able KW, Nemerson DM, Bush R, Light P (2001) Spatial variation in Delaware Bay (USA) marsh creek fish assemblages. Estuaries 24(3):441-452

Able KW, Nemerson DM, Light PR, Bush RO (2002) Initial response of fishes to marsh restoration at a former salt hay farm bordering Delaware Bay. In: Weinstein MP, Kreeger DA (eds) Concepts and controversies in tidal marsh ecology. Kluwer Academic, Dordecht, p 749-773

Baltz DM, Rakocinski C, Fleeger JW (1993) Microhabitat use by marsh-edge fishes in a Louisiana estuary. Environ Biol Fishes 36:109-126

Bretsch K, Allen DM (2006) Tidal migrations of nekton in salt marsh intertidal creeks. Estuar Coast 29(3):479-491

Cain RL, Dean JM (1976) Annual occurrence, abundance and diversity of fish in a South Carolina intertidal creek. Mar Biol 36:369-379

Cattrijsse A, Makwaia ES, Dankwa HR, Hamerlynck O, Hemminga MA (1994) Nekton communities of an intertidal creek of a European estuarine brackish marsh. Mar Ecol Prog Ser 109:195-208

Cicchetti G, Diaz RJ (2000) Types of salt marsh edge and export of trophic energy from marshes to deeper habitats. In: Weinstein MP, Kreeger DA (eds) Concepts and controversies in tidal marsh ecology. Kluwer Academic, Dordecht, p 515-541

Coen LD, Luckenbach MW, Breitburg DL (1999) The role of oyster reefs as essential fish habitat: a review of current knowledge and some new perspectives. Am Fish Soc Symp 22:438-454

Craig JK, Crowder LB (2000) Factors influencing habitat selection in fishes with a review of marsh ecosystems. In: Weinstein MP, Kreeger DA (eds) Concepts and controversies in tidal marsh ecology. Kluwer Academic, Dordecht, p 241-267

Dame, RF (1996) Ecology of marine bivalves: an ecosystem approach. CRC Press, Boca Raton, FL

Dame R, Childers D, Koepfler E (1992) A geohydrologic continuum theory for the spatial and temporal evolution of marsh-estuarine ecosystems. Neth J Sea Res 30:63-72

Dame R, Bushek D, Allen D, Edwards D and 7 others (2000) The experimental analysis of tidal creeks dominated by oyster reefs: the premanipulation year. J Shellfish Res 19(1):361-369

Dame R, Bushek D, Allen D, Lewitus A, Edwards D, Koepfler E, Gregory L (2002) Ecosystem response to bivalve density reduction: management implications. Aquat Ecol 36: $51-65$

Deegan LA, Hughes JE, Rountree RA (2000) Salt marsh ecosystem support of marine transient species. In: Weinstein MP, Kreeger DA (eds) Concepts and controversies in tidal marsh ecology. Kluwer Academic, Dordecht, p 333-365

Desmond JS, Zedler JB, Williams GD (2000) Fish use of tidal creek habitats in two southern California salt marshes. Ecol Eng 14:233-252

Fischer P, Eckmann R (1997) Seasonal changes in fish abundance, biomass and species richness in the littoral zone of a large European lake, Lake Constance, Germany. Arch Hydro 139(4):433-448

Fretwell SD (1972) Populations in a seasonal environment. Princeton University Press, Princeton, NJ

Gibson, RN (1999) Movement and homing in intertidal creek fishes. In: Horn MH, Martin KLM, Chotkowski MA (eds) Intertidal fishes: life in two worlds. Academic Press, London, p 97-125
Gibson RN (2003) Go with the flow: tidal migration in marine animals. Hydrobiologia 503:153-161

Glancy TP, Frazer TK, Cichra CE, Lindberg WJ (2003) Comparative patterns of occupancy by decapod crustaceans in seagrass, oyster, and marsh-edge habitats in a northeast Gulf of Mexico estuary. Estuaries 26(5):1291-1301

Hettler WF Jr (1989) Nekton use of regularly-flooded saltmarsh cordgrass habitat in North Carolina, USA. Mar Ecol Prog Ser 56:111-118

Holland AF, Sanger DM, Gawle CP, Lerberg SB, Santiago MS, Riekerk GHM, Zimmerman LE, Scott GI (2004) Linkages between tidal creek ecosystems and the landscape and demographic attributes of their watersheds. J Exp Mar Biol Ecol 298(2):151-178

Jongman RHG, ter Braak CJF, van Tongeren OFR (1995) Data analysis in community and landscape ecology. Cambridge University Press, Cambridge

Kneib RT (1997) The role of tidal marshes in the ecology of estuarine nekton. Oceanogr Mar Biol Annu Rev 35: $163-220$

Kneib RT (2000) Salt marsh ecoscapes and production transfers by estuarine nekton in the southeastern United States. In: Weinstein MP, Kreeger DA (eds) Concepts and controversies in tidal marsh ecology. Kluwer Academic, Dordecht, p 267-291

Kneib RT (2003) Bioenergetic and landscape considerations for scaling expectations of nekton production from intertidal marshes. Mar Ecol Prog Ser 264:279-296

Kramer DL, Chapman MR (1999) Implications of fish home range size and relocation for marine reserve function. Environ Biol Fishes 55:65-79

Kramer DL, Rangeley RW, Chapman LJ (1997) Habitat selection patterns of spatial distribution from behavioural decisions. In: Godin JJ (ed) Behavioural ecology of teleost fishes. Oxford University Press, New York, p 37-80

Lehnert RL, Allen DM (2002) Nekton use of subtidal oyster shell habitat in a southeastern US estuary. Estuaries 25(5):1015-1024

Lotrich VA (1975) Summer home range and movements of Fundulus heteroclitus (Pisces: Cyprinodontidae) in a tidal creek. Ecology 56(1):191-198

McIvor CC, Odum WE (1988) Food, predation risk, and microhabitat selection in a marsh fish assemblage. Ecology 69(5):1341-1351

McIvor CC, Rozas LP (1996) Direct nekton use of intertidal saltmarsh habitat and linkage with adjacent habitats: a review from the southeastern United States. In: Nordstrom KF, Roman CT (eds) Estuarine shores: evolution, environments and human alterations. John Wiley \& Sons, New York, p 311-334

Minello TJ, Zimmerman RJ, Medina R (1994) The importance of edge for natant macrofauna in a created marsh. Wetlands 14:184-198

Minello TJ, Able KW, Weinstein MP, Hays CG (2003) Salt marshes as nurseries for nekton: testing hypotheses on density, growth and survival through meta-analysis. Mar Ecol Prog Ser 246:39-59

Paterson AW, Whitfield AK (2003) The fishes associated with three intertidal salt marsh creeks in a southern African estuary. Wetl Ecol Manag 11:305-315

Peterson GW, Turner RE (1994) The value of salt marsh edge vs. interior as a habitat for fish and decapod crustaceans in a Louisiana tidal marsh. Estuaries 17(1B):235-262

Pittman SJ, McAlpine CA, Pittman KM (2004) Linking fish and prawns to their environment: a hierarchical landscape approach. Mar Ecol Prog Ser 283:233-254

Potthoff M, Allen DM (2003) Site fidelity, home range, and 
tidal migrations of juvenile pinfish, Lagodon rhomboides, in salt marsh creeks. Environ Biol Fishes 67:231-240

Rakocinski CF, Baltz DM, Fleeger JW (1992) Correspondence between environmental gradients and the community structure of marsh-edge fishes in a Louisiana estuary. Mar Ecol Prog Ser 80:135-148

Rozas LP, Odum WE (1987) Use of tidal freshwater marshes by fishes and macrofaunal crustaceans along a marsh stream-order gradient. Estuaries 10(1):36-43

Rozas LP, Zimmerman RJ (2000) Small-scale patterns of nekton use among marsh and adjacent shallow nonvegetated areas of the Galveston Bay Estuary, Texas (USA). Mar Ecol Prog Ser 193:217-239

Rozas LP, McIvor CC, Odum WE (1988) Intertidal rivulets and creekbanks: corridors between tidal creeks and marshes. Mar Ecol Prog Ser 47:303-307

Ruiz GM, Hines AH, Posey MH (1993) Shallow water as a refuge habitat for fish and crustaceans in non-vegetated estuaries: an example from Chesapeake Bay. Mar Ecol Prog Ser 99:1-16

SAS Institute (1996) SAS/STAT user's guide, version 6.12. Cary, NC

Shenker JM, Dean JM (1979) The utilization of an intertidal salt marsh creek by larval and juvenile fishes: abundance, diversity and temporary variation. Estuaries 2(3)154-163

Simenstad A, Hood, WG, Thom RM, Levy DA, Bottom DL (2002) Landscape structure and scale constraints on restoring estuarine wetlands for Pacific Coast juvenile

Editorial responsibility: Howard Browman (Associate Editorin-Chief), Storebø, Norway fishes. In: Weinstein MP, Kreeger DA (eds) Concepts and controversies in tidal marsh ecology. Kluwer Academic, Dordecht, p 597-630

Steward-Oaten A, Murdoch WW, Parker KR (1986) Environmental impact assessment: 'Pseudoreplication' in time. Ecology 67:929-940

Webb SR, Kneib RT (2002) Abundance and distribution of juvenile white shrimp Litopenaeus setiferus within a tidal marsh landscape. Mar Ecol Prog Ser 232:213-223

Weinstein MP, O'Neil SP (1986) Exchange of marked juvenile spots between adjacent tidal creeks in the York River Estuary, Virginia. Trans Am Fish Soc 115:93-97

Weinstein MP, Weiss SL, Walters MF (1980) Multiple determinants of community structure in shallow marsh habitats, Cape Fear River Estuary, North Carolina, USA. Mar Biol 58:227-243

Wenner EL, Beatty HR (1993) Utilization of shallow estuarine habitats in South Carolina, USA, by postlarval and juvenile stages of Penaeus spp. (Decapoda: Penaeidae). J Crustac Biol 13(2):280-295

Wenner E, Beatty HR, Coen L (1996) A method for quantitatively sampling nekton on intertidal oyster reefs. J Shellfish Res 15(3):769-775

Williams GD, Zedler JB (1999) Fish assemblage composition in constructed and natural tidal marshes of San Diego Bay: relative influence of channel morphology and restoration history. Estuaries 22(3A):702-716

Zar JH (1996) Biostatistical analysis, 3rd edn. Prentice Hall, London

Submitted: November 9, 2005; Accepted: May 24, 2006

Proofs received from author(s): December 20, 2006 